\title{
Retur fra foreldrepermisjon for turnusleger
}

\author{
Turnusleger som går ut i foreldrepermisjon i løpet av den perioden de har tjeneste i kommune, har ingen \\ garanti for å kunne fortsette turnustjenesten når de selv ønsker det.
}

Foreldrepermisjon er en rettighet. Det betyr at arbeidsgiver ikke kan nekte å innvilge permisjon. Det er i utgangspunktet opp til den enkelte arbeidstaker å bestemme når permisjonen starter og slutter. Arbeidstaker må selvsagt varsle arbeidsgiver, med de frister som følger av arbeidsmiljøloven, men arbeidsgiver har normalt ingen rolle i å påvirke varigheten av permisjonen. Spørsmålet er om turnusleger har samme rett som øvrige arbeidstakere til selv å bestemme når permisjonen er over.

Utgangspunktet for denne artikkelen er to saker om turnuslegers rett til å komme tilbake til tjeneste i kommune etter foreldrepermisjon - nærmere bestemt på hvilket tidspunkt de har rett til å komme tilbake. Den ene saken gjaldt en kvinnelig turnuslege, den andre en mannlig turnuslege i pappapermisjon.

I begge sakene ble legene pålagt ufrivillig ventetid i flere måneder, fordi turnustjeneste i utgangspunktet starter 1. mars eller 1. september. Stønadsperioden for foreldrepenger gikk ut flere måneder før, og de risikerte en lang periode uten lønn. Legeforeningen brakte sakene inn for Likestillings- og diskrimineringsombudet, også kalt ombudet, for uttalelse. I begge sakene fikk vi medhold $i$ at arbeidsgiver brøt likestillingsloven.

\section{Diskriminering \\ og forskjellsbehandling}

Likestillingsloven forbyr diskriminering på grunn av kjønn. Diskriminering på grunn av graviditet og permisjon ved fødsel eller adopsjon regnes også som diskriminering på grunn av kjønn.

Med forskjellsbehandling mener likestillingsloven at en person blir stilt dårligere på grunn av foreldrepermisjonen enn personen ville vært uten permisjonen. Forskjellsbehandling er kun lovlig når følgende tre vilkår er oppfylt: den har et saklig formål, er nødvendig for å oppnå formålet og det er et rimelig forhold mellom det man ønsker å oppnå og hvor inngripende forskjellsbehandlingen er.

\section{Ombudets vurdering}

Ombudet konkluderte med at turnuslegene i begge sakene var blitt forskjellsbehandlet ved at de risikerte flere måneder uten lønn etter foreldrepermisjonen. Ombudets gjen- nomgang viste at årsakene til forskjellsbehandlingen var saklige, men ikke nødvendige, og at det derfor var brudd på likestillingsloven.

I den ene saken kom ombudet til at forskjellsbehandlingen ikke var nødvendig fordi det fantes alternativer som kommunen ikke hadde forsøkt, for eksempel å vurdere å opprette midlertidig plass. Ettersom ombudet

\section{«Det skal mye til for at ufrivillig ventetid er forholdsmessig»}

konkluderte med at forskjellsbehandlingen ikke var nødvendig, behøvde det ikke ta stilling til om det siste vilkåret, forholdsmessighet, var oppfylt. Ombudet valgte likevel å si noe om dette.

Hovedpoenget var at hensynet til det økonomiske tapet som foreldrene risikerte ved ulønnet permisjon, eller det familiære tapet ved å måtte ta kortere permisjon, var en betydelig større belastning enn kommunens belastning. Legeforeningen oppfatter at ombudet med dette antyder at forskjellsbehandlingen heller ikke var forholdsmessig.

I den andre saken hadde kommunen vurdert flere alternativer. Likevel kom ombudet til at forskjellsbehandlingen ikke var nødvendig. I kommunen ble turnuslegene ansatt omtrent ett år i forveien. Det betyr at det kun unntaksvis er en ledig stilling som en turnuslege kan gjeninntre i etter permisjon. Kommunen ga ingen god forklaring på hvorfor det var nødvendig å ansette så tidlig, og ombudet kom til at det ikke var sannsynliggjort at det var nødvendig. Dermed var heller ikke forskjellsbehandlingen nødvendig - og med det i strid med likestillingsloven.

Sakene som er omtalt her, er hentet fra kommunehelsetjenesten. Når det gjelder turnusleger i sykehus, har legene de samme rettighetene som sine kolleger med tjeneste i kommune. Men i tillegg har de rettigheter etter overenskomsten del A2 $\S 8.3 .3$. Av den følger at de har rett til å fortsette sin turnustjeneste ved samme tjenestested etter endt permisjon $o g$ at de beholder ansettelsesforholdet i permisjonen, med tilsvarende forskyvning av fratreden.

Turnusleger har dermed bedre rettigheter ved permisjon fra sykehus enn ved permisjon fra kommunehelsetjenesten i og med at arbeidsforholdet opprettholdes i permisjonstiden. I kommunehelsetjenesten utløper arbeidsforholdet etter seks måneder, selv om turnuslegen har rett til å fullføre resttjenesten i kommunen etter permisjonen.

\section{Når kan turnuslegen kreve \\ å komme tilbake?}

Ombudet konkluderte med at turnusleger

ikke kan kreve å komme tilbake på den eksakte datoen permisjonen er over. Det som likevel er klart, er at arbeidsgiver ikke kan ha som rutine at legen automatisk må vente på nærmeste 1. mars eller 1. september.

Arbeidsgiver kan heller ikke passivt vente og se om det blir en ledig turnuslegestilling. Den må gjøre reelle forsøk på å få til tidligere gjeninntreden. I tillegg må arbeidsgiver ha en ansettelsespraksis som gjør det mulig å planlegge slik at leger i permisjon kan komme tilbake så tett opp til ønsket dato som mulig.

Selv om turnuslegen ikke kan kreve å få komme tilbake på akkurat ønsket dato, må kommunen vurdere muligheten for at legen kan komme tilbake da. Hvis det ikke går, må kommunen legge til rette for at ventetiden skal bli så kort som mulig. I tillegg viser ombudets uttalelse i den første saken at det skal mye til for at ufrivillig ventetid er forholdsmessig. Uten slik forholdsmessighet er forskjellsbehandlingen i strid med likestillingsloven.

\section{Liv Marit Fagerli \\ liv.marit.fagerli@legeforeningen.no}

Liv Marit Fagerli er advokat/spesialrådgiver og ansatt i Avdeling for jus og arbeidsliv, Legeforeningen. Fra 1. januar 2017 har hun permisjon fra stillingen for å arbeide som avdelingssjef/ advokat på Akershus universitetssykehus. Forfatter har fylt ut ICMJE-skjemaet og oppgir ingen interessekonflikter. 